[Regular Paper]

\title{
Studies on Catalytic Hydrotreating of Recycled Solvents from Coal Liquefaction Process (Part 2) Investigation of Kinetics, Catalyst Deactivation and Prediction of Catalyst Life
}

\author{
Yasuo Morimura $^{\dagger 1}$, Shin-ichi Nakata ${ }^{\dagger 1)}$, Yoshikazu Yokota ${ }^{\dagger 1)}$, Yoshimi Shiroto ${ }^{\dagger 1)}$, \\ Munekazu NaKamura ${ }^{\dagger 1)}$, Yukuaki Mitarai ${ }^{\dagger 2}$, and Yoshimasa InOUE ${ }^{\dagger 3}$ \\ 1) Chiyoda Corporation, 3-13 Moriya-cho, Kanagawa-ku, Yokohama 221 \\ +2) Sumitomo Metal Mining Co., Ltd., 5-11-3 Shinbashi, Minato-ku, Tokyo 105 \\ (3) Nippon Ketjen Co., Ltd., 1-5-9 Shiba, Minato-ku, Tokyo 105
}

(Received November 25, 1993)

\begin{abstract}
The following items have been reported based on the results of a series of catalytic hydrotreating tests of feed solvents obtained from a coal liquefaction process using $\mathrm{Ni}-\mathrm{Mo} /$ alumina catalyst: (1) the kinetics of the hydrogenation of the recycled solvents obtained from a $1 \mathrm{t} /$ day PDU liquefaction process using Wandoan and Illinois No. 6 (River King) coals; (2) their reactivities on hydrogenation; (3) the catalyst deactivation during a $3,000 \mathrm{~h}$ test run using recycled solvent derived from Wandoan coal and a proposal of simple mathematical model and its application to the long run test data; (4) the prediction of catalyst life from hydrotreating tests of the recycled solvents prepared from Wandoan and Illinois No. 6 coals by maintaining constant hydrogenation rates.
\end{abstract}

\section{Introduction}

One of significant matters required of coal liquefaction processes is to produce solvents containing high donatable hydrogen by hydrogenation of middle distillates of the coal derived oils, and to recycle them to a liquefaction stage as hydrogen donor solvents ${ }^{1}$.

In this paper, the results of a series of the hydrotreating tests, using a commercially available $\mathrm{Ni}-\mathrm{Mo} /$ alumina catalyst, are reported, as listed bellow:

(1) The kinetics of the hydrogenation of recycled solvents obtained from a $1 \mathrm{t} /$ day Process Development Unit (PDU) liquefaction process using Wandoan and Illinois No. 6 (River King) coals.

(2) The reactivity of recycled solvent on hydrogenation.

(3) The deactivation of catalyst during a $3,000 \mathrm{~h}$ test run of the recycled solvent obtained from Wandoan coal, and the proposal of simple mathematical models for deactivation of catalyst and the application of the model to the results of the long run test data.

(4) The prediction of catalyst life (temperature-

* To whom correspondence should be addressed. time relation) during hydrotreating of recycled solvents derived from Wandoan and Illinois No. 6 coals.

\section{Experimental}

\section{1. Feed Solvents}

Three kinds of middle distillates (feed solvents $\mathrm{A}, \mathrm{B}$ and $\mathrm{C}$ ) derived from a $\mathrm{lt} /$ day PDU coal liquefaction process were used as feedstocks for hydrotreating. For our experiments, Wandoan and Illinois No. 6 coals were used. The operation modes of the process are shown in Table 1. The properties and distributions of hydrocarbon compounds of these solvents are given in Table 2 and Fig. 1, respectively. The differences in properties and chemical compositions, especially in aromaticity $(f a)$, between feed solvents $\mathrm{A}$ and $\mathrm{B}$ are attributed to the differences between the operation modes. The difference in the content of $350^{\circ} \mathrm{C}^{+}$ fraction is due to the difference in the cut points of hydrotreated products $\left(200^{\circ} \mathrm{C}\right.$ for feed solvent A and $220^{\circ} \mathrm{C}$ for feed solvent $\mathrm{B}$ ).

The liquefaction process of these two coals were operated under the same conditions, and the differences in the physical properties and chemical compositions between feed solvents $\mathrm{B}$ and $\mathrm{C}$ are 
Table 1 Operation Model of $1 \mathrm{t} /$ day PDU

\begin{tabular}{lccc}
\hline \multicolumn{1}{c}{ Feed solvent } & A & B & C \\
\hline Source & Wandoan coal & Wandoan coal & Illinois No. 6 coal \\
$\Delta f a^{a}$ & $<0.03$ & $\sim 0.1$ & $\sim 0.1$ \\
Recycled type of $350^{\circ} \mathrm{C}^{+}$fraction & Partial & Extinction & Extinction \\
& & (NEDOL mode) & (NEDOL mode) \\
\hline
\end{tabular}

a) Degree of hydrogenation at which the hydrotreating was conducted.

Table 2 Properties of Feed Solvents

\begin{tabular}{|c|c|c|c|}
\hline Feed solvent & A & B & C \\
\hline Specific gravity, $d 25 / 4^{\circ} \mathrm{C}$ & 1.0104 & 0.9616 & 1.0288 \\
\hline \multicolumn{4}{|l|}{ Ultimate analysis $\quad[\mathrm{wt} \%]$} \\
\hline Carbon & 89.23 & 88.98 & 88.41 \\
\hline Hydrogen & 8.26 & 10.21 & 8.65 \\
\hline Oxygen & 2.2 & 0.4 & 1.8 \\
\hline Total nitrogen & 0.41 & 0.22 & 0.61 \\
\hline Basic nitrogen & 0.31 & 0.12 & 0.35 \\
\hline Sulfur & 0.07 & 0.16 & 0.12 \\
\hline Average molecular weighta) & 181 & 229 & 202 \\
\hline$n$-Paraffins $\quad[$ wt $\%]$ & 9.0 & 14.13 & 3.0 \\
\hline Aromaticity $(f a)^{\text {b) }}$ & 0.68 & 0.48 & 0.60 \\
\hline $350^{\circ} \mathrm{C}^{+}$content & 17 & 31 & 35 \\
\hline
\end{tabular}

a) Obtained from FI-Mass spectrum.

b) Obtained from ${ }^{13} \mathrm{C}-\mathrm{NMR}$ spectrum.
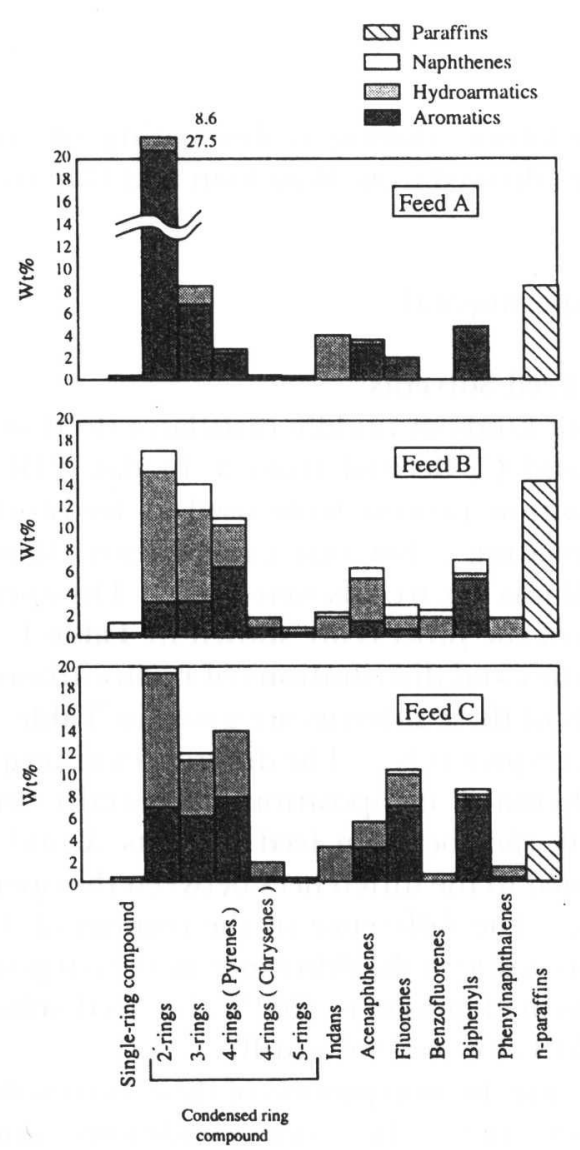

Fig. 1 Composition of Hydrocarbons of Feed Solvents
Table 3 Reaction Conditions of Hydrotreating Tests

\begin{tabular}{lrl}
\hline Temperature & {$\left[{ }^{\circ} \mathrm{C}\right]$} & 320 to 400 \\
Hydrogen pressure & {$\left[\mathrm{kg} / \mathrm{cm}^{2}-\mathrm{G}\right]$} & 50 to 100 \\
LHSV & {$\left[\mathrm{h}^{-1}\right]$} & 1.0 to 3.0 \\
Hydrogen to liquid ratio & {$[\mathrm{Nl} / \mathrm{l}]$} & 1,000 \\
\hline
\end{tabular}

probably attributed to the inherent differences between the coal types. High gravity, aromaticity $(f a)^{1)}$, and concentration of nitrogen and oxygen are characteristics of feed solvent C. Feed solvent $\mathrm{C}$ also has a higher concentration of fluorenes, and four-ring type of condensed aromatic compounds. On the other hands, a higher content of $n$-paraffins is characteristic of solvents A and B. Thus, coal type and the operation mode of the liquefaction process affect the properties of the recycled solvents.

\section{2. Catalyst and Reaction Conditions}

The hydrotreating tests were performed using fixed-bed reactors ${ }^{2}$. The catalyst was a commercial by available $\mathrm{Ni}-\mathrm{Mo} /$ alumina extrudate, $1 / 16$ inch in diameter. The conditions for the determination of the reaction kinetics and the catalysts reactivities are given in Table 3. Long run tests (ca. 3,000 h) using feed solvent A were performed to study changes in catalyst activities, such as temperature dependency of catalyst deactivation during hydrotreating. The conditions of the long run tests were: temperatures, 334 , 
$350,380^{\circ} \mathrm{C}$; hydrogen pressure, $100 \mathrm{~kg} / \mathrm{cm}^{2}-\mathrm{G}$; LHSV, $1.0 \mathrm{~h}^{-1}$; hydrogen to liquid ratio in volume, $1,000 \mathrm{~N} l / l$.

\section{Results and Discussion}

\section{1. Kinetics of Hydrogenation}

Solvents consist of various types of compounds and, therefore, the determination of hydrotreating rate equations, solely using recycled solvent data, is more difficult than using model compound data. To obtain the apparent overall reaction rate equation in feed, the kinetics were investigated using a method which assumes that the concentration of the reactant is equal to an initial value of one. This method is typically used in kinetic studies of hydrodesulfurization (HDS) of petroleum fractions ${ }^{3}$.

During hydrotreating, various reactions, such as the hydrogenation of aromatic-rings and the removal of hetero-atom, occur in parallel. This work focused on the hydrogenation of aromaticrings. Since solvents are mixtures of various aromatic compounds, characterizations of individual reactions for each compound are not possible. The hydrogenation reaction rate, therefore, was represented by the rate of decrease in $f a$ values.

\section{1. 1. Order of Reaction}

Catalyst activity became nearly constant after $400 \mathrm{~h}$, and the data obtained during this period were used to calculate the reaction order. The reaction order of the hydrogenation was calculated using the experimental data, which were obtained as LHSV changed from 1.0 to $3.0 \mathrm{~h}^{-1}$. The first order plots of hydrogenation for feed solvents $\mathrm{A}$ and $\mathrm{C}$ are shown in Fig. 2. Since the plots are linear, hydrogenation is a first order reaction.

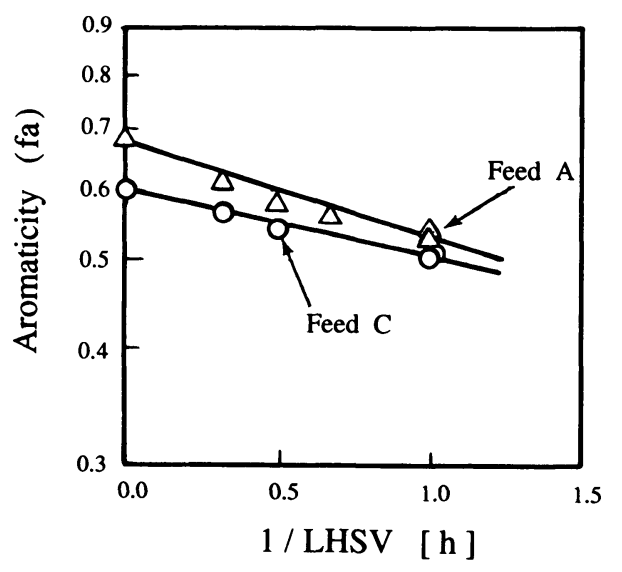

Fig. 2 First-order Reaction Plots on Hydrogenation

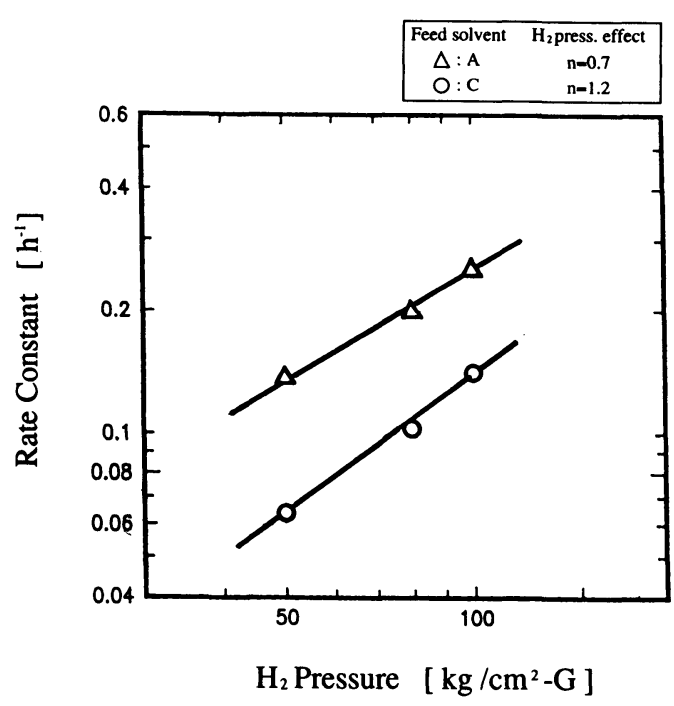

Fig. 3 Effect of Hydrogen Pressure on Hydrogenation

\begin{tabular}{|c|c|}
\hline Feed Solvent & $\begin{array}{c}\text { Acvivation Energy } \\
\text { E , (kcal/mol ] }\end{array}$ \\
\hline$\Delta: A$ & $17\left(320 \sim 360^{\circ} \mathrm{C}\right)$ \\
$\mathrm{O}: \mathrm{C}$ & $15\left(300 \sim 360^{\circ} \mathrm{C}\right)$ \\
\hline
\end{tabular}

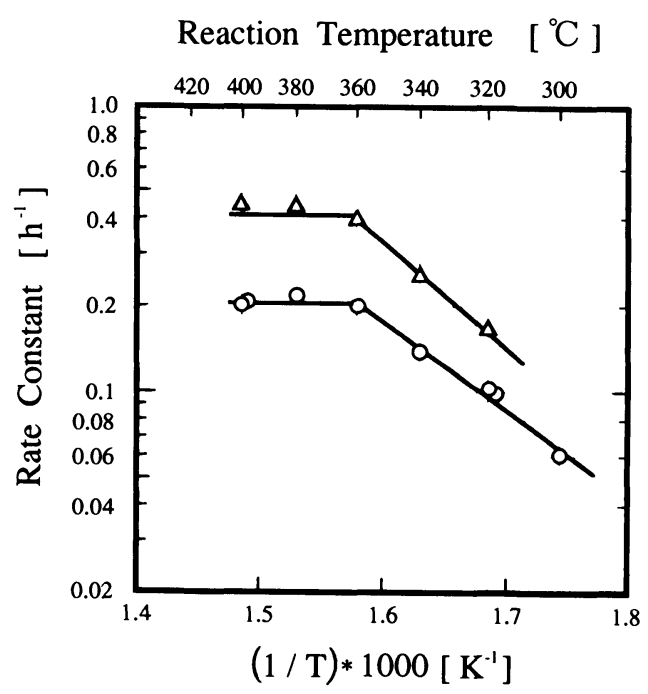

Fig. 4 Temperature Dependencies on Hydrogenation

\section{1. 2. Effect of Hydrogen Pressure}

The effect of hydrogen pressure on the reaction rate constants was investigated. Figure 3 shows the results for feed solvents A and C. From these results, the effect of hydrogen pressure was found to be represented by Eq. (1):

$$
k \propto P_{\mathrm{H}_{2}}{ }^{n}
$$

where, $P_{\mathrm{H}_{2}}$ : hydrogen pressure $\left(\mathrm{kg} / \mathrm{cm}^{2}-\mathrm{G}\right)$ 
The exponent for feed solvent $\mathrm{C}$ was greater than that for A.

\section{1. 3. Temperature Dependency}

Dependency on reaction temperature of the rate constants was investigated. Arrehnius' plots are shown in Fig. 4. The apparent activation energies [ $\mathrm{kcal} / \mathrm{mol}]$, were as follows:

Feed solvent A: 17 (during $320-360^{\circ} \mathrm{C}$ )

Feed solvent C: 15 (during $300-360^{\circ} \mathrm{C}$ )

The apparent activation energies for hydrogenation are different for temperatures below and above $360^{\circ} \mathrm{C}$. For temperatures above $360^{\circ} \mathrm{C}$, dehydrogenation occurring competitively with hydrogenation is substantial, accounting for the lower apparent activation energies. The difference of these activation energies is probably due to the difference in hydrocarbon composition of solvents shown in Fig. 1.

\section{1. 4. Equation for Overall Reaction Rate}

The equation for apparent overall reaction rate for hydrogenation is represented by Eq. (2):

$$
\mathrm{d} f / \mathrm{d}(\mathrm{LHSV})=-r=A \cdot \exp (-E / R T) \cdot\left(P_{\mathrm{H} 2} / 100\right)^{n} \cdot f
$$

\section{2. Comparison of Reactivities}

To study the reactivities of hydrogenation of recycled solvents, several hundred hours of hydrotreating, for quantitative interpretation from the catalyst activities and their changes, is required. The reactivities of the three feed solvents (A, B and $\mathrm{C}$ ) were investigated. The changes in the hydrogenation rate constant, normalized at the conditions of $340^{\circ} \mathrm{C}$ and $100 \mathrm{~kg} / \mathrm{cm}^{2}-\mathrm{G}$ of hydrogen pressure, as a function of time-on-stream, are shown in Fig. 5.

No appreciable changes were found in the

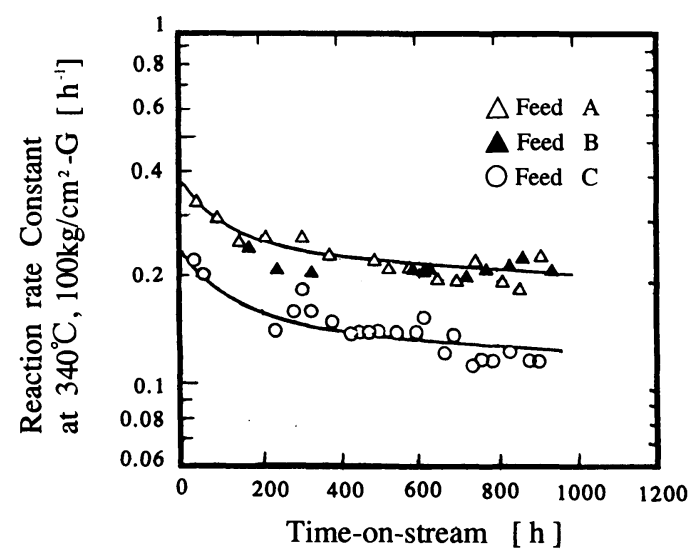

Fig. 5 Comparison of Reactivities of Solvents A, B and C on Hydrogenation reactivities between feed solvents $A$ and $B$, but the reactivity of $C$ was lower than those of $A$ and $B$. The hydrogenation rate constants at $400 \mathrm{~h}$ were 0.24 and 0.14 for feed solvents A and C, respectively. The difference in reactivity between these two solvents may be ascribed to the differences in their physical properties and chemical compositions. A higher amount of $350^{\circ} \mathrm{C}^{+}$fraction and fluorenes, which can be difficult to hydrogenate, was observed in the feed solvent derived from Illinois No. 6 coal.

Hydrogen input is very important for hydrotreating of recycled solvents in coal liquefaction processes. A significant relation exists between the degree of hydrogenation and the presence of donatable hydrogens from recycled solvents in the hydrotreating step of the processes. One of the important purposes of hydrotreating is to provide donatable hydrogen to solvents. Thus, the change in the amount of donatable hydrogens during the hydrotreating of solvents was investigated. The amount of donatable hydrogens $\left(D_{\mathrm{H}}\right)$ in feed solvents and hydrotreated oils was obtained by ${ }^{1} \mathrm{H}-\mathrm{NMR}$ method as follows ${ }^{1)}$ :

$$
D_{\mathrm{H}}=H_{\mathrm{D}} \cdot H_{\mathrm{T}}
$$

where, $H_{\mathrm{D}}=\left(h_{\alpha} / x\right)+\left(h_{\mathrm{n}} / y\right)$

$h_{\alpha}$ : the ratio of protons of $\alpha$-methylenes to the total amount of protons from the ${ }^{1} \mathrm{H}-\mathrm{NMR}$ spectrum ( $\delta$ 2.3-3.0 ppm in ${ }^{1} \mathrm{H}$-chemical shift)

$h_{\mathrm{n}}$ : the ratio of protons of $\beta$-methylenes to total proton of protons $\left(\delta 1.6-2.0 \mathrm{ppm}\right.$ in ${ }^{1} \mathrm{H}$ chemical shift)

$H_{\mathrm{T}}$ : total hydrogen content $(\mathrm{wt} \%)$ $x=y=2$

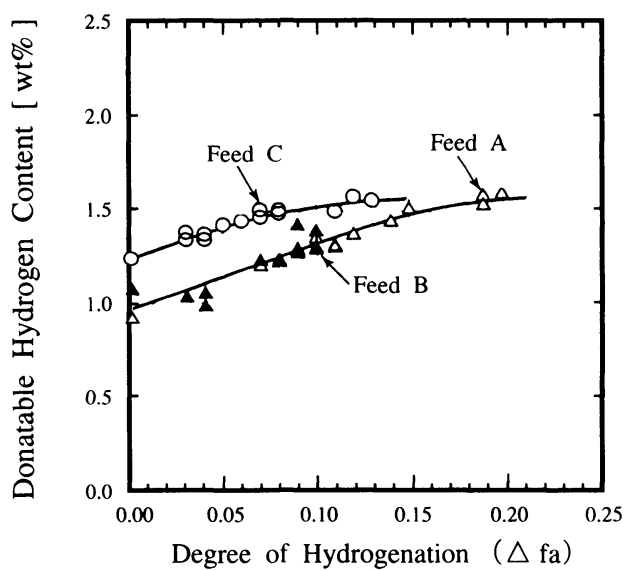

Fig. 6 Changes in Donatable Hydrogen Contents as a Function of Degree of Hydrogenation 
Shown in Fig. 6 are changes in the amount of donatable hydrogens as a function of the degree of hydrogenation $(\Delta f a) . \quad \Delta f a$, obtained by ${ }^{13} \mathrm{C}-\mathrm{NMR}$, denotes the change in $f a$ between the feed solvent and hydrotreated oil. The greater the value of $\Delta f a$ shows, the greater the hydrogenation of solvents proceeds. The amount of donatable hydrogens from feed solvents A and B shows increase proportional with the first increase in $\Delta f a$. For both solvents, however, the increase became gradual above a $\Delta f a$ of approximately 0.15 . For feed solvent $\mathrm{C}$, the proportional increase changes to a more gradual one above $\Delta f a$ of approximately 0.08 . The different profiles between solvents $\mathrm{A} / \mathrm{B}$ and $\mathrm{C}$ are attributed to the difference in hydrocarbon composition of solvents, shown in Fig. 1. The profiles of the change in the amount of donatable hydrogens during hydrotreating of solvents correspond to the changes in their chemical composition. During hydrotreating, the amount of donatable hydrogens increases with the increase in amount of hydroaromatic compounds ${ }^{1}$. The amount of donatable hydrogens assinged to hydroaromatic compounds, however, becomes saturated with the increase in chemical hydrogen consumption, suggesting an increase in the amount of naphthenes ${ }^{1)}$.

When hydrotreating of recycled solvents is considered from the aspect of contents of donatable hydrogens, a hydrotreating operation keeping $\Delta f a$ at appropriate values to preserve are evidently required as is investigated above. The values of the $\Delta f a$ in the standard operating conditions of $1 \mathrm{t} /$ day PDU are between 0.03 and 0.1 .

\section{3. Catalyst Deactivation in Hydrotreating of Recycled Solvents}

\section{3. 1. Long Run Test Results}

For the design and operation of reactors in hydrotreating processes, it is important to collect long run test experimental and kinetic data of catalyst deactivation during hydrotreating. In consideration thereof the long run test for feed solvent A was continuously conducted for $c a$. $3,000 \mathrm{~h}$.

The change in aromaticity $f a$ given in Fig. 7 indicates the gradual degradation of catalyst

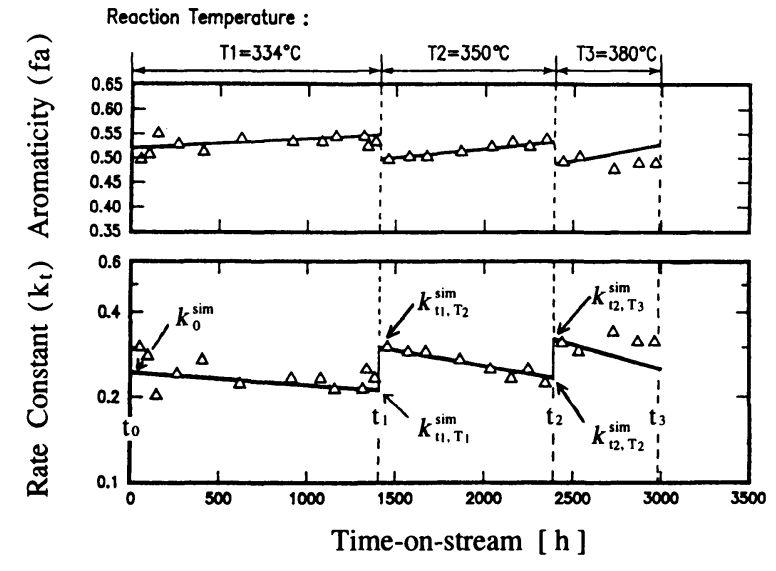

Fig. 7 Change in Aromaticity and Rate Constant on Hydrogenation in the Long Run Test

activity during hydrogenation with time-onstream, in each temperature range. After the long run test, the used catalyst was divided into five parts, and three of these parts were analyzed for the amount of deposited carbon and their physical properties. The analyzed results of the used and fresh catalysts are shown in Table 4. The amount of the deposited carbon was $c a .12$ to $18 \mathrm{wt} \%$, based on the fresh catalyst weight. The pore volume of catalyst decreased with carbon deposition. In addition, the surface area of the used catalyst was ca. 30 to $40 \%$ less than that of the fresh catalyst. Since no element other than carbon was detected by ultimate analysis, the catalyst deactivation must have been caused by the changes in the pore structures of catalysts with the deposition of carbonaceous materials on the surface of the catalyst.

\section{3. 2. Applying the Model of Catalyst Deactiva- tion}

As described above, deactivation of catalyst during hydrotreating of recycled solvents is primarily caused by deposition of carbonaceous materials. The behavior of carbon deposition on the catalyst, therefore is a dominant factor governing the deactivation and life of the catalyst. Deactivation catalyst caused by carbon deposition on the catalyst during the upgrading processes of coal derived oil

Table 4 Changes of Catalyst Properties and Deposited Carbon

\begin{tabular}{lcccc}
\hline & \multirow{2}{*}{ Fresh catalyst } & \multicolumn{3}{c}{ Used catalyst } \\
\cline { 3 - 5 } & & Inlet & Middle & Outlet \\
\hline Physical properties & & & & \\
$\quad$ Surface area $\left[\mathrm{m}^{2} / \mathrm{g}\right]$ & 269 & 155 & 166 & 183 \\
$\quad \begin{array}{c}\text { Pore volume }[\mathrm{m} l / \mathrm{g}] \\
\text { Deposited carbon }\end{array}$ & 0.53 & 0.21 & 0.24 & 0.29 \\
$\quad[$ wt\% on fresh catalyst] & - & 17.6 & 14.4 & 12.5 \\
\hline
\end{tabular}


by HDN and/or HDS have been reported in several studies $^{4) ~ 7)}$. However, a model of catalyst deactivation for hydrotreating of coal-derived oils has not been proposed to date, because sufficient quantitative elucidation on the relation between the change in feed oils and the rate of carbon deposition may still be lacking. In this work, catalyst deactivation during hydrogenation was studied in accordance with a method proposed by Krishnaswamy et al. ${ }^{8)}$. Assuming that fixed-bed reactors employed in the hydrotreating were operated with an isothermal plug flow, catalyst deactivation could be analyzed based on a model of concentration-independent deactivation. In accordance with the model, the degree of catalyst deactivation $(\psi)$ is defined by Eq. (4):

$$
\psi=k_{t} / k_{0}
$$

where, $k_{0}$ : reaction rate constant at the start-ofrun, $t=0$

$k_{t}$ : reaction rate constant at $t$ in time-onstream.

The reaction rate constant of hydrogenation at $t$ of a given value of LHSV is represented by Eq. (5):

$$
\begin{aligned}
& k_{t}=k_{0} \psi=\ln \left(f_{0} / f\right) \mathrm{LHSV} \\
& k_{0}=A_{\mathrm{d}} \cdot \exp \left(-E / \mathrm{RT}_{0}\right)
\end{aligned}
$$

For a first order, concentration-independent decay, the change in catalyst deactivation with time is given by Eq. (7):

$$
-(\mathrm{d} \psi / \mathrm{d} t)=k_{\mathrm{d}} \cdot \psi
$$

where, $k_{\mathrm{d}}$ is the deactivation rate constant, which indicates an Arrehenius' temperature dependence, as described below.

$$
k_{\mathrm{d}}=A_{\mathrm{d}} \cdot \exp \left(-E_{\mathrm{d}} / R T\right)
$$

Substitution of Eq. (8) into Eq. (7) and integration give:

$$
\psi=\exp \left\{-A_{\mathrm{d}} \cdot \exp \left(-E_{\mathrm{d}} / R T\right) \cdot t\right\}
$$

where, $A_{\mathrm{d}}$ : frequency factor for catalyst deactivation

$E_{\mathrm{d}}$ : activation energy for catalyst deactivation.

With the substitution of Eq. (9) into Eq. (4), the reaction rate constant for a case where catalyst deactivaion at $t$ is as follows;

$$
k_{t}=k_{0} \cdot \exp \left\{-A_{\mathrm{d}} \cdot \exp \left(-E_{\mathrm{d}} / R T\right) \cdot t\right\}
$$

The reaction rate constant, when catalyst deactivation is considered in each temperature range as shown in Fig. 7, is represented by Eqs. (11), (12) and (13)

$$
\begin{aligned}
& \text { For } t=t_{0}-t_{1} \text { and } T=T_{1} \text {, } \\
& k_{t}^{\text {sim }}=k_{0} \cdot \exp \left\{-A_{\mathrm{d}} \cdot \exp \left(-E_{\mathrm{d}} / R T_{1}\right) \cdot t\right\} \\
& \text { For } t=t_{1}-t_{2} \text { and } T=T_{2} \text {, } \\
& k_{t}^{\text {sim }}=k_{t_{1}}{ }^{\operatorname{sim}_{\mathrm{T}_{1}}} \cdot \exp \left[-E / R \cdot\left(T_{2}^{-1}-T_{1}^{-1}\right)\right] \cdot \\
& \exp \left\{-A_{\mathrm{d}} \cdot \exp \left(-E_{\mathrm{d}} / R T_{2}\right) \cdot\left(t-t_{1}\right)\right\} \\
& k_{t}^{\text {sim }}=k_{t_{2}}{ }^{{ }^{s i m}} \mathrm{~T}_{2} \cdot \exp \left[-E / R \cdot\left(T_{3}{ }^{-1}-T_{2}^{-1}\right)\right] \cdot \\
& \exp \left\{-A_{\mathrm{d}} \cdot \exp \left(-E_{\mathrm{d}} / R T_{3}\right) \cdot\left(t-t_{2}\right)\right\}
\end{aligned}
$$

$A_{\mathrm{d}}$ and $E_{\mathrm{d}}$, the kinetic parameters of catalyst deactivation on hydrogenation, was optimally estimated by the least squares method, using Eqs. (11), (12), and (13). Their values were obtained, using a reaction rate constant from the long run test data obtained by computer simulation based on the following objective function:

$$
\operatorname{Min} \Sigma\left(k_{t}^{\text {sim }}-k_{t}{ }^{\text {exp }}\right)^{2}
$$

where, $\quad k_{t}^{\text {sim }}$ : reaction rate constant at $t$ obtained from Eqs. (11), (12), and (13)

$k_{t}{ }^{\text {exp }}$ reaction rate constant obtained from the long run test data

$A_{\mathrm{d}}$ and $E_{\mathrm{d}}: 2.4 \times 10^{4}$ and $[\mathrm{kcal} / \mathrm{mol}]$, respectively.

The comparison of the test data (triangle marks) with the simulation data (solid lines) are shown in Fig. 7, indicating good agreement. Thus, the model of catalyst deactivation on the hydrogenation of recycled solvents was found to be applicable to a first-order reaction. The influence of hydrogen pressure and the hydrogen to liquid ratio on the catalyst deactivation was not included, however, since the test was performed while these two conditions were held constant. The applicability of the present model of catalyst deactivation, therefore, is limited to the conditions of $100 \mathrm{~kg} / \mathrm{cm}^{2}-\mathrm{G}$ of hydrogen pressure and 1,000 $\mathrm{N} l / l$ of hydrogen to liquid ratio.

\section{4. Prediction of Catalyst Life in Hydrotreating of Recycled Solvents}

Generally, the operating method, which maintains the conversion of hydrogen at a given level by a rise in reactor temperature, corresponds to the degree of catalyst deactivation with time-on-stream and has been adopted for commercial reactors in the HDS of petroleum light fractions. Catalysts are usually exchanged or regenerated when the maximum temperature for the reactors is reached. 
For hydrotreating of recycled solvents on a commercial scale, a similar operating method, as described above, can be adopted.

Using $A_{\mathrm{d}}, E_{\mathrm{d}}$, and the reaction temperature required to attain the intended degree of hydrogenation by Eq. (10), temperature-time curves can be simulated. In this work, the influence of the degree of hydrogenation and of the characteristics of feed solvents on catalyst life were investigated.

\section{4. 1. Influence of the Intended Degree of $\mathrm{Hy}$ - drogenation}

A temperature-time relation was estimated, based on the model using the parameters of catalyst deactivation during hydrotreating of solvent A from Wandoan coal. Shown in Fig. 8, the simulated temperature-time curves as the $\Delta f a$ between the feed solvents and hydrotreated oils is set at $0.05,0.1$ and 0.15 , respectively. The figure serves to indicate that the $\Delta f a$ needed to keep in the operation had an appreciable influence on the catalyst life. Abrupt changes of the curve above $360^{\circ} \mathrm{C}$ were not due to catalyst deactivation, but could be attributed to the temperature effect of dehydrogenation occurring competitively with hydrogenation.

\section{4. 2. Influence of Characteristics of Feed Solvents}

The influence of the characteristics of feed solvents on catalyst life is attributable to properties of coal and to the operating modes of the coal liquefaction process, including hydrotreating. The reaction rate constants at $400 \mathrm{~h}$ in time-onstream $\left(k_{0}\right)$ of feed solvents A, B and C used in the simulation were $0.25,0.25$ and 0.14 , respectively. It was assumed that the values of the rate parameters for catalyst deactivation, $A_{\mathrm{d}}$ and $E_{\mathrm{d}}$, for feed solvents B and C were equal to those of feed solvent A.

Shown in Fig. 9 are simulated temperature-time curves during hydrotreating for each feed solvent,

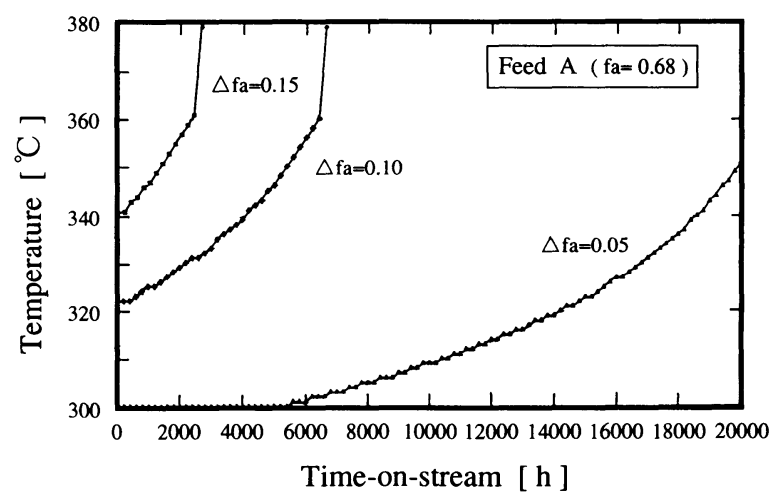

Fig. 8 Prediction of Temperature-time Curve (dependency on degree of hydrogenation, $\Delta f a$ )

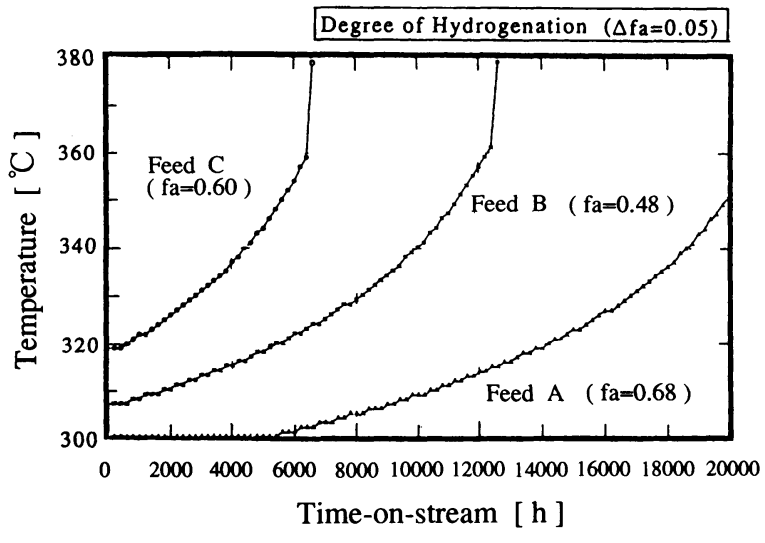

Fig. 9 Prediction of Temperature-time Curve (dependency on characteristics of feed solvent)

when $\Delta f a$ is set at 0.05 . Despite the same coal properties and similar hydrogenation reactivities, the catalyst life with feed solvents $A$ and $B$ appreciably different. This difference can be attributed to the unlike $f a$ of the feed solvents and to the varying operating mode of the $1 \mathrm{t} /$ day PDU, as shown in Table 1. For feed solvents A and C, an appreciable difference in catalyst life was found. The difference in hydrogenation reactivity was due to the variances in the characteristics of the coal.

From this study, it was found that the catalyst life during hydrotreating fluctuated widely by differing operating mode of the coal liquefaction process, including hydrotreating; the characteristics of employed solvents; the intended degree of hydrogenation; and the reactivity of hydrogenation.

\section{Acknowledgment}

This work was made possible through the kind support of the New Energy and Industrial Technology Development Organization (NEDO) as one of the commissioned projects included in the "Sunshine Plan" programs. The authors are grateful to NEDO for the permission to contribute this paper.

\section{References}

1) Morimura, Y., Nakata, S., Yokota, Y., Shiroto, Y., Nakamura, M., Mitarai, Y., Inoue, Y., Sekiyu Gakkaishi, 38, (4), 221 (1995).

2) Morimura, Y., Nakata, S., Akimoto, O., Kodama, S., Nakamura, M., Sekiyu Gakkaishi, 38, (3), 185 (1995).

3) Speight, J.G., "The Desulfurization of Heavy Oils and Residue," Marcel Dekker, New York (1981).

4) Ahmed, M.W., Ph. D. Dissertation, Oklahoma State University, 1979.

5) Mehta, D.C., Ph. D. Dissertation, Oklahoma State 
University, 1978.

6) Chang, H.J., Ph. D. Dissertation, Oklahoma State University, 1982

7) Duraisway, K., Ph. D. Dissertation, University of Utah,
1973

8) Krishnaswamy, S., Kittrell, J.R., Ind. Eng. Chem., Process Des. Dev., 18, 399 (1979).

要旨

\title{
石炭洨化プロセスからの循環溶㓮の接触水羑化処理に関する研究（第 2 報） 功力学的検时，触媒の活性劣化の検时および笋命予測
}

\author{
森村恭郎 ${ }^{\dagger 1)}$ ，中田真一 ${ }^{\dagger 1)}$ ，横田善一 ${ }^{\dagger 1)}$ ，白戸義美 ${ }^{(1)}$ ， \\ 中村宗和 ${ }^{11)}$, 御手洗征明 ${ }^{\dagger 2)}$, 井上好昌 ${ }^{\dagger 3}$ \\ †1) 千代田化工建設(株)，221 横浜市神奈川区守屋町 3-13 \\ †2）住友金属鉱山(株)，105 東京都港区新橋 5-11-3 \\ †3）日本ケッチェン(株)，105 東京都港区芝 1-5-9
}

石炭液化油からの循環溶剤の接触水素化処理に関して一連の 研究を行ってきたが，本報では， $\mathrm{Ni}-\mathrm{Mo} /$ /アミナ系触媒を用 いて次の項目について検討した。（1）ワンドアン炭およびイリ ノイNo.6（リバーキング）炭を原料炭とする $1 \mathrm{t}$ /日 PDUの 液化プロセスから得られた循環溶剤の水素化反応の動力学的検 討，（2）これら溶剤の水素化反応性に関する検討，（3）ワン
ドアン炭液化油からの循環溶剤の 3,000 時間にわたる水素化処 理試験における触媒の性能変化，特に活性劣化について。触媒 の活性少化のシミュレーションに対する数学的モデルの適用お よび水素化処理の長期運転試験のデー夕に対する適用，(4) 循 環溶剤の水素化度を一定に保持しての水素化反応における触媒 寿命の予測。

\section{Keywords}

Coal liquid, Hydrogenation, Catalyst deactivation, Catalyst life, Kinetics, Hydrocarbon 